\title{
DIRECTIONS AND PECULIARITIES OF TERRITORIAL FUNCTIONAL CHANGES IN A MEDIUM SIZE UKRAINIAN TOWN IN THE POST-SOVIET PERIOD OF DEVELOPMENT (CASE OF BERDYCHIV)
}

\author{
'Anatoliy MELNYCHUK, Oleh KHMELNYTSKYI \\ Taras Shevchenko National University of Kyiv, Ukraine \\ 'melan97@ukr.net
}

\begin{abstract}
The article contains information about transformation of the functional structure of Berdychiv from the second half of the XX century to the beginning of the XXI century. Attention is focused on a turning point in the development of functional space, specifically the transition from command-administrative to market economy in the 1990s. The analyze focuses on a permanent transitional period of town development during the XX century and the beginning of the XXI century, when new forms of functional and spatial structure arise and simultaneously the old structures still continue to exist. Factual evidence demonstrates the influence of dynamic and continuous processes of territorial functional transformation on the development of the mosaic functional space of the town. The study revealed an impact of both advanced service sector development (primarily trade, banking, insurance and credit activities, public services and catering) and a reduction of the role of large industry on the town space. Space transformations, identified in Berdychiv, are connected with the change of prevailing functions. The authors revealed the main type-forming features of territorial use according to the territorial functional load, offered classification of the service facilities of various kinds within the limits of the study area according to the determined criteria, and identified the spatial transformation cores and their impact on the spatial modernization within the town of Berdychiv.
\end{abstract}

Key words: spatial transformations, function of the territory, core of spatial transformation, spatial modernization, town

UDC: $911.3: 352(69)$

\section{НАПРЯМИ ТА ОСОБЛИВОСТІ ЗМІНИ ФУНКЦІЇ ТЕРИТОРІЇ СЕРЕДНЬОГО МІСТА В УКРАЇНІ У ПОСТРАДЯНСЬКИЙ ПЕРІОД РОЗВИТКУ (НА ПРИКЛАДІ МІСТА БЕРДИЧІВ)}

\author{
'Анатолій МЕЛЬНИЧУК, Олег ХМЕЛЬНИЦЬКИЙ \\ Київський начіональний університет імені Тараса Шевченка, Україна \\ 'melan97@ukr.net
}

Анотація: У статті розглядається трансформація функціональної структури міста Бердичів протягом другої половини XX століття - початку XXI століття. Акцентується увага на переламному періоді у розвитку функціонального простору міста - 90 -х роках XX століття - переході від командно-адміністративного ладу до ринкової моделі економіки. Аналізується перманентний стан перехідного періоду розвитку, характерного для міста XX - початку XXI ст., коли виникають нові форми функціональнопросторової структури, а стара структура ще продовжує існувати. Відображено вплив динамічних та безперервних процесів перетворення функційтериторіїна формуваннямозаїчного функціональногопросторуміста. Визначено вплив наперетворення міського простору випереджаючого розвитку закладів сфери обслуговування (насамперед, торгівлі, банківської, страхової та кредиторської діяльності, обслуговування населення та громадського харчування) та зменшення ролі великих промислових підприємств. Виявлено просторові трансформації в межах м. Бердичів, пов'язані зі зміною його переважаючих функцій. Розкрито основні типоформуючі ознаки використання його території відповідно до їхнього функціонального навантаження. Запропоновано типізацію об'єктів різних видів діяльності в межах району дослідження за визначеними ознаками. Встановлено просторові ядра трансформації та їх вплив на модернізацію території м. Бердичів.

Ключові слова: просторові трансформації, функція території, ядро просторової трансформації, модернізація простору, місто

Удк: 911.3:352(69)

\section{INTRODUCTION}

Fundamental spatial transformations have happened in cities due to Soviet Union breakup and the transition to the marketeconomy. The command-administrative system with its strict and too regulated approach to planning the town space stopped to work and a new structure began to form according to the changed conditions. Due to the crisis in economy, former leading and town-forming industrial plants began to be closed and rearranged, and instead of these plants the sphere of human services (especially commerce) received all-round development and in particular started to place its objects in the buildings of

(c) А. Мельничук, О. Хмельницький the former industrial plants. The new factor, which began to influence significantly the development of the town face and caused the change of functions of the town areas on the post-Soviet space, is business: first small-scale and not well organized, and then big and organized, related with building up and creating trading networks of new type [Axenov K., Brade I., Bondarchuk E., 2006; Stanilov, 2007]. This, to a large extent, has limited the possibilities of the town community and ordinary citizens to influence on the modern town face development and shifted the focus from the authority of state functionaries to the authority of business and combined authority of both business and state functionaries. Practically, regular town inhabitants don't have the opportunity to make free use of town life benefits that is considered as a basic modern 
civil right [Lefebvre H., 1991]. Spatial transformations and development of the urban areas under the impact of the global privatization processes and the fight of the community for «the right of the town» ( according to A. Lefebvre) have been discussed in the studies of the leading urbanists and geourbanists [Davis M, 2006; Kohn M., 2004; Low S., Smith N., 2006; Mitchell D, 1995; Zukin 1995].

The spatial transformations took place in all the cities of the former Soviet Union that followed the path of the market transformations, and the town of Berdychiv was not an exception. This town with a medium population is a striking example of such changes and their consequences.

\section{STUDY AREA, GOAL AND OBJECTIVES}

The goal of this research is to identify the functional transformations of the territory within the town of Berdychiv at the time of transition from commandadministrative to market economy and to investigate the impact of these functions on the spatial transformations within the limits of the town.

Tasks of the research are the following: to reveal the main functions of the town territory during certain historical-geographical cross-sections; to classify the objects of different kinds of activity according to determined criteria; to define the functional zones within the limits of the studied territory; to analyze the spatial transformations that took place at the time of economic changes; to reveal the new territorial development cores.

During transition period, medium size towns of the post-Soviet space suffered from a significant negative impact on their development. With retrogress, industrial, predominantly large plants experienced serious challenges for their development and the necessity for modernization with the aim to create competitive urban territories. In crisis times, development of towns, connected with the change of the economic set-up, sharpened a problem of controlling space modification processes with a task to avert the changing of comfortable ways of communication, parks, squares, and peculiar historical constructions in downtowns with enlarged highways, parking lots, office centers, and monotone commercial buildings [Linch K., 1960; Jacobs J., 1961]. For this reason we chose the town of Berdychiv, being typical Ukrainian town with a medium population, as a case for our research.

\section{CHAPTER THREE}

The solution of the formulated problems has been conducted during the following phases of investigation:

1) Preparatory phase. During this phase initial statistic information was collected according to a chosen complex of indexes. Different sources of information were used for this aim: statistical yearbook of Zhytomyr oblast, statistical compendiums, magazines, newspapers, monographs, articles, Internet-resources. During the preparatory phase we gathered all the necessary information about the functional use of the town territory at the time of command-administrative economy system. We determined routes and schedules how to carry out field researches and selected for the research the main and the most representational streets from the different town districts (modern center, historical center and remote areas): European Street, Vinnytska Street and Cathedral Street in the Central micro-district; Zhytomyrska Street in the micro-district of the city hospital and the tannery; Kotovsky Street in the micro-district of Chervona Hora and Eling; Vojkova Street in the micro-district of Zagrebelya and Chervona Street in the micro-district of the sugar mill.

2) Field phase. During this phase we realized the research of the functional use of the territory along the selected streets. From the 17 to the 21 of June we explored European Street (the main street of the town), its total length is $2.5 \mathrm{~km}$. From the 22 to 23 of June we investigated Vinnitska Street, its length is $1.4 \mathrm{~km}$. On the 24 of June we explored Cathedral Street, its length is $570 \mathrm{~m}$. From the 27 to the 30 of June we explored Zhytomyrska Street, its length is $4 \mathrm{~km}$. On the 2 of July we investigated Kotovsky Street, its length is $4.4 \mathrm{~km}$. On the 4 of July we explored Vojkova Street, its length is $2.5 \mathrm{~km}$. Finally, on the 5 of July we investigated Chervona Street, its length is $2.2 \mathrm{~km}$.

3) Cameral phase. During this phase, based of the compiled information during preparatory and field stages, we created a database demonstrating the functional use of the territory at the selected historical-geographical crosssections. Also we composed the relevant skeleton maps and realized the analysis of changes happened between the year 1970 (before the beginning of «stagnation» in the Soviet Union economy) and the present day.

\section{RESULTS AND DISCUSSIONS}

Formation and development of the market relations and building the new forms of economy go inseparably with the transformation processes of towns, urban culture, urban consciousness, creation of the specific urban environment. Not by chance the representatives of different scientific disciplines (philosophy, geography, municipal engineering, economics, history, sociology, ecology etc.) are unusually interested now in researching the social and economic development of towns. This is because the towns not only keep economic, demographic, financial, intellectual and cultural potential of society but also continue to accumulate it.

Passage to the market relations has changed fundamentally the determinative economic and social characteristics of regions, districts and municipal units. These changes mainly affected the medium size towns and the large cities where the decentralization of control of the social and economic processes had the biggest consequences. In modern conditions it is of key importance to stir up the roles of small and medium towns in the regional development. Especially in this category of towns we can see evidently the positive and negative consequences of adoption of the social and economic reforms; the development of small and medium towns to a greater extent stipulates for the further social and economic development of the regions and the country as a whole. In light of this a problem of social and economic development of the small and medium 
towns and the strategic management of this development is deemed to be of significant importance.

Study of directions and peculiarities of changing the functions of the urban areas is a difficult interdisciplinary task which is directed to reveal the corresponding mechanisms and tendencies of their optimization in modern conditions.

The term «function» in the broader sense is treated as «correlation that defines the order of the insertion of a part in the whole», that is why by function of the towns we will mean the activity of enterprises and organizations which characterize participation of the town in division of the scopes of activity, and formation by them of living conditions for population. In order that the town will be able to perform some function, an element or a group of elements that are specialized in performing this function should be formed in its territory. The main functions of the town are the following: industrial, transport, administrative, commercial, cultural, scientific, educational, touristic, communal etc. [Kharkiv].

The urban area can relatively quickly change its functions. The time of changing of the function depends on factors that stimulate these changes [Melnychuk A., Palchuk M.]. At the same time the main functions of the town materialize strongly on its territory and with time it is not so easy to change them.

With the aim to define the concrete functions of some territory it is necessary to realize the functional zoning of this territory (to divide the town into parts of different destination on the basis of the dominant function: work, civilian life, household activities, rest). The functional zone is a territorial area or a summation of areas of spreading of a certain function of the town.

The town of Berdychiv experienced the change of the sectoral structure of economy: the increase of number of people working in human services, reduction of those who work for industry, liquidation of large industrial enterprizes and the change of functions of the production territories.

The transfer of Ukraine from the post-Soviet period of development of the urban areas to the commercial one and the construction of a new system of economic and social relations strengthened the variety of land tenure within the town, the prevailing amplification of one functions (often new) within the concrete territory and the slackening of other functions.

The study of the dominant functions of the urban territories is a difficult interdisciplinary task which is directed to reveal the corresponding mechanisms and tendencies of their optimization in modern conditions.

Speaking about the functions of urban settlement, S. Kovalev distinguishes the town-forming functions and the town-serving functions. According to the author's opinion, this division is the most appropriate and permits to determine the dominant function of the town in the certain historical stage of its development. The townserving functions correspond to the kinds of activity and branches that supply and serve only the population of the town. The most typical examples are the internal town transport and the bread-baking industry. But every town has own prevailing complex of clearly defined functions that create the most important substratum for city life, so called town-forming functions, stimulating the development of other functions. The towns that lost their principal specialization due to extinction of some functions are obliged to rearrange themselves to new directions under the influence of new functions. The atrophy of dominant function and the lack of functionssuccessors often result in stagnation and even decay of the town [Kharkiv].

The industry turned the main town-forming function in Berdychiv during the command-administrative system of economy. The Soviet power, because of the ideological convictions, deliberately destroyed the historical town-forming function of Berdychiv, specifically the commerce (international trade fairs, state auctions), and replaced it with the industrial function by constructing and reequipping such industrial enterprises as MachineBuilding Plant "Progress", Machine-Tool Building Plant "Komsomolets", Illich Tannery, malting plant, sugar-refinery mill, garment factory, gloves factory, leather and footwear industrial complex, brickmaking plant, brewery etc. Well-developed system of social infrastructure (medical, cultural, sporting, child's) and green zones (town squares, parks), except to serve to the public and to demonstrate the ideology, served primarily for normalization of Soviet people, consolidation and reproduction of the Soviet type of standards [Engel 2007, 287-290]. After the Soviet Union breakup and passing of the town economy to the market conditions the role of industry has reduced and the commerce, being the historical town-forming function, experienced renascence. The dynamic change of functions gave the town the possibility to minimize the effects of stagnation and to avoid the decline.

During the field phase of research we revealed, classified and analyzed the principal functions of the territories adjacent to the main streets of the town. All the social services can be classified according to necessity and specialization. According to the necessity the social services can be classified on: everyday; of temporal demand; unique. According to the specialization the social services can be classified on: commercial, public services, catering, banking and insurance activities, educational, religious, medical and administrative.

By analyzing the databases it was defined that in the market conditions in the town of Berdychiv, according to the necessity, the services (a total of 568 objects have been tested) distributes as follows: $22 \%$ of services are everyday; $58 \%$ - services of the temporal demand; $20 \%-$ unique services. According to the specialization we have the following situation: $59 \%$ of services are commercial, $18 \%$ - public services; $8 \%$ - catering, 5\% - banking and insurance activities, 4\% - administrative, 3\% educational, 1\% - medical and religious.

Below it is shown the distribution of services according to necessity and specialization in every particular street.

European Street: according to necessity, 20\% of services were everyday; $63 \%$ - services of the temporal demand; $17 \%$ - unique services. According to specialization, $54 \%$ were commercial, $20 \%$ - public services; $11 \%$ - catering, 5\% -administrative services, $4 \%$ - educational and banking services, $1 \%$ - religious 
and medical. Using this data we can distinguish such parts of the street according to the dominant functions: 1) From the Central department store to the Town Executive Committee (prevalence of commercial services and catering); 2) From the Town Executive Committee to the House of Culture (prevalence of commerce and public services); 3) From the Town Executive Committee to the railway station (prevalence of commercial services and catering).

Vinnytska Street: according to necessity, 17\% of services were everyday; $59 \%$ - services of the temporal demand; $24 \%$ - unique services. According to specialization, $62 \%$ were commercial, $23 \%$ - public services; $9 \%$ - catering, 3\% - banking and religious services. Using this data we can distinguish such parts of the street according to the dominant functions: 1) From the Cathedral square to the shopping centre "Passage" (prevalence of commercial services and catering); 2) From the shopping centre "Passage" to the shopping centre "Continent" (prevalence of commercial services and public services); 3) From the shopping centre "Continent" to the micro-district "Children's world" (prevalence of commercial services).

Zhytomyrska Street: according to necessity, $15 \%$ of services were everyday; $58 \%$ - services of the temporal demand; $27 \%$ - unique services. According to specialization, $63 \%$ were commercial, $14 \%$ - public services, $7 \%$ - banking services, $6 \%$ - administrative services, $5 \%$ - catering, $2 \%$ - medical services, $1 \%$ educational services. Using this data we can distinguish such parts of the street according to the dominant functions: 1) From the town market to the municipal hospital (prevalence of commercial services); 2) The micro-district of the municipal hospital (prevalence of medical and commercial services); 3) The micro-district of the meat-packing factory (prevalence of commercial services, public services and catering).

Kotovsky Street: according to necessity, 36\% of services were everyday; $51 \%$ - services of the temporal demand; $13 \%$ - unique services. According to specialization, $67 \%$ were commercial, $13 \%$ - public services; $10 \%$ - catering, $5 \%$ - administrative services, $3 \%$ - educational services, $1 \%$ - medical and religious services.

Cathedral Street: according to necessity, 9\% of services were everyday; $61 \%$ - services of the temporal demand; $30 \%$ - unique services. According to specialization, $58 \%$ were commercial, $24 \%$ - public services, $12 \%$ - banking services, $6 \%$ - catering.

Vojkova Street: according to necessity, $50 \%$ of services were everyday; $36 \%$ - services of the temporal demand; $14 \%$ - unique services. According to specialization, $65 \%$ were commercial, $14 \%$ - educational services, $7 \%$ - public services, catering and medical services.

Chervona Street: according to necessity, 38\% of services were everyday; $52 \%$ - services of the temporal demand; $10 \%$ - unique services. According to specialization, $51 \%$ were commercial, $14 \%$ - public services, $10 \%$ - religious and educational services, $5 \%-$ banking, medical services and institutions of catering.

The central part of the town (European, Cathedral,
Vinnytska and partly Zhytomyrska streets) concentrates the unique services and the services with the temporal demand.

The dwelling districts of the town (Kotovsky, Vojkova, Chervona and partly Zhytomyrska streets) predominantly are focused the everyday services meeting the daily needs of local population.

By analyzing the databases it was defined that at the time of a planned economy in the town of Berdychiv, according to necessity, $32 \%$ of services were everyday; $37 \%$ - services of the temporal demand; $31 \%$ - unique services (a total 167 objects have been tested). According to specialization, the situation was the following: $53 \%$ of services were commercial, $10 \%$ - public services; $7 \%-$ catering, $15 \%$ - administrative, $12 \%$ - educational, $2 \%$ - medical, and $1 \%$ - religious services.

The number of businesses representing the services sector has increased significantly, largely due to the reequipment of the ground floors of the common dwelling houses and the building of new shopping centers. There is evidence of heredity in the location of the businesses: in modern market conditions the great number of businesses is situated in the same places where the institutions with similar or identical functions were located at the time of a planned economy. The banking services generally are offered in the central part of the town, in the old houses with fetching architecture and big storefronts. The significant part of them locates in the Cathedral Street. Predominately these buildings are the so called "stalinky" (Stalin-era buildings) giving the place for restaurants and the grocery stores at the time of a planned economy.

The functional use of the premises of plants and factories has changed significantly. In the conditions of transition to the market economy and the economic crisis after the Soviet Union collapse, the big plants and factories began to lose industrial facilities, operating personnel, and some of them were shut down at all. That is why people began to give for rent or sale many industrial and other locations, plants and factories, and because of this now we can find there different services by necessity and specialization. Those situated in the main streets of the town are chiefly specialized in the commercial, banking services and the catering. Those situated in the outlying districts has turned into servicing (re-equipment of minibuses, car washes, tire fittings, etc.) or the manufacturing enterprises (production of tombstones, windows and doors, etc.). The striking example of such functional changes is the use of the premises of the plant "Progress", Illich Tannery, and the sugar-refinery mill. In the second part of the XX century these industrial facilities acted the main town-forming function and provided their workers with new residential houses and complexes, sports and recreation centers. The plant "Progress" is the only one that could adapt itself to the present market conditions, while Illich Tannery and the sugar-refinery mill were unable to adapt to the new economic conditions, so lost a competition and stopped to operate. Nowadays, the majority of buildings of these industrial projects are let on lease for different forms of activity. Thereby this territory has changed drastically its functional use from industrial to chiefly commercial, banking and partially manufacturing. 
The industrial core of the town has changed considerably in sizes and capacities if to compare it with the 1970-80th.

The maximum concentration of the commercial services is observed in the market places ("Municipal Market", "Railroad Market", "Southern Market", "Chervona Hora Market"). All these markets (save for "Municipal Market") were created in time of market economy. The local government constructed "The new central municipal market" in the district of quartermaster's, but because of some mistakes in the placement it could not substitute the historically formed "The municipal market" and now it doesn't exercise its functional purpose.

The enterprises of distribution networks became appreciably widespread, for example: "Fora", "ATBMarket", "Kvartal", "Nash Krai", "Polissia-Product" etc.

The largest number of catering facilities is observed in the main street of the town (European Street), in particular there is a significant accumulation of such facilities near a railway station. In this specialization the changes appeared only on terms of location and weren't functional.

The big area in the central part of the town is taken up by the dwelling houses. For this reason there are many facilities of social infrastructure here (such as hospitals, kindergartens, schools) and human services (groceries and nonfood stores, hairdressing saloons, network of domestic service).

The central part of the town concentrates an appreciable quantity of architectural monuments and old buildings of historical and cultural value. This determines the investment attraction of this zone, and therefore it is necessary to stimulate investments for preservation and reconstruction of these monuments (or renovation of their facades).

We observed significantly increased number of religious centers that were prohibited in the Soviet period. During the time of independence the former religious buildings renewed their functional use, and also a large number of new religious objects was constructed and restored.

Also there is a boom of private health care institutions. All the rest (administrative, educational, medical services) in the spatial sense remained in places of their allocation since the period of a planned economy.

\section{The cores of urban growth}

It should be noted that research discovered radical functional changes and development of new transformation cores in some parts of the town. The most substantial transformations took place in the central part of the town, especially around the shopping center "Lemon" and the Central Square.

In particular, a new trade core rendering unique services and the services of temporary demand arose around the shopping center "Lemon". At the same time this territory simultaneously is a place for the hotel and restaurant business development represented by a fourstar hotel "Déjà vu". Service to the public is represented by the center of photos. In the days of commandadministrative system all this territory was a purely dwelling zone. Such innovations as the hotel "Déjà vu" and the shopping centre "Lemon" in the very historical centre organically blended with the historical space and now they don't seem as stranger objects, moreover they give a new sense and a new life to the historical

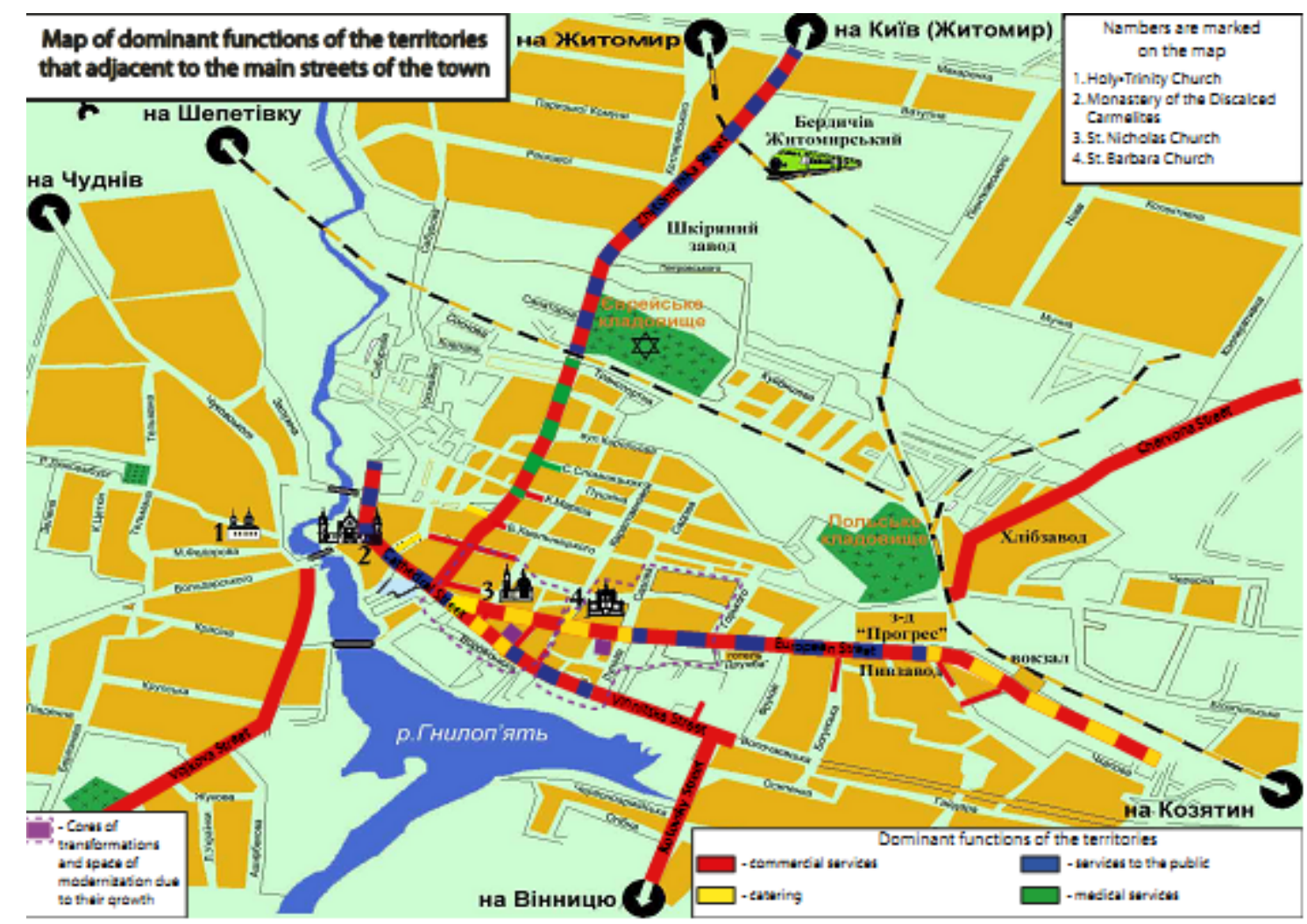

Fig. 1. Dominant functions of the territories adjacent to the main streets of the town, 2013. 
space. People who prepared the projects and those who confirmed architectural decisions managed to find a compromise between the functional maintenance of new objects and their historical environment. The forming of the core resulted in modernization of the adherent territory, where functional changes did not happen, but the objects of infrastructure changed their profile, level of service, modernized facades and etc.

The territory around the Central Square has also radically changed its functionality. In the days of the command-administrative system it was a place of the ordinary one-storied dwelling-houses, but today in the market conditions this area became one of the most important centers of commercial, office, entertaining and cultural services in the town. The multifunctional trade complex "Balzac" and the shopping centre "Mix" were built here, and together with the cardinal reconstruction of the square this has changed its functional use. The construction of themultifunctional trade complex "Balzac" is the striking example of the fact that the modern spatial transformation of the town is directed at the creation of symbology that promotes the image of Berdychiv as the successful center of coexistence of many nationalities. The construction in the Central Square was associated with the closeness to the catholic Saint Barbara's Church, where in 1850 the known French writer Honore de Balzac was married. In the complex there is a museum dedicated to Honore de Balzac's writing, and the conference hall for the meetings of the representatives of Ukraine and France. Beside the MTC entrance a monument has been established in honor of the writer.

As a whole, taking into account the transformation of the functionality from chiefly dwelling to the business and commercial, it is possible to affirm that these zones are still on the stage of development and are perspective for locating here facilities for commercial, business, and recreational services. The space between the mentioned cores of the space transformation has been marked by functional modernization subordinated to these cores (the confluence of influence zones of the transformation cores). This is the most attractive part of the town which not only didn't lose in the period of political and economic transformations, but won and gradually returns the attraction of this territory for individuals, who nowadays are the principal asker for changes, and not for the system as it was in the Soviet period. Here someone may feel the possibility of the town renascence as a regional center, as the post-industrial town, ecologically friendly to population.

At the same time, the former cores of development that mainly were represented by the large plants ("Progress", "Komsomolets", tannery, sugar-refinery mill) and the nearby territories have lost their value in the functional load of the territory. The large number of industrial and other spaces began to be rented or sold by plants and factories giving the place for different services by necessity and specialization. Those spaces situated on the main streets are chiefly specialized on commercial, banking services or catering, exploiting the modernization potential of the new (renewed from the pre-soviet times) transformation cores. Those located in the outlying districts are rearranged in the servicing (rearrangement of minibuses, car-washings, tire-montages etc.) or industrial services (producing of tombstones, windows and doors). With their decline the space around them lost its potential of development and has signs of existence in conditions of the permanent crisis.

In accordance with our research, the large areas are used ineffectively; it means that they don't cope with the functional loading of this zone. For example, large territory is occupied by buildings of the former plant "Komsomolets" (now "Bevers"). It drops out from the general functional structure of the area with typical recreational function. After the Soviet Union breakup this industrial object couldn't adapt itself to the new market conditions and produce the competitive product. Also, the place for construction of this plant was badly chosen: at sufficient distance from the railway lines, in the middle of the town recreational zone "pedestrian bridge - embankment - municipal beach", and this considerably decreased the attraction of this zone for allocation here catering facilities, entertaining and hotel-restaurant services etc. This situation is a striking example of displacement of the extraneous element from the functional spatial structure of the town.

\section{Conclusions}

The urban environment has considerably transformed with the change of the economic system. The intense development has happened in the sphere of the consumers services (the large development had commercial, banking, insurance and credit activities, service to the public and catering), while the role of large industrial plants and factories has reduced.

Obtained results may comprise a scientific background for analysis of the transformation process of predominant functions of the town territories, and can be used for elaboration and introduction of measures for optimization the functional loading of the corresponding zones and the effective organization of the urban space.

Study of urban functional transformation allows determining the mechanisms of the perspective development of the town. Thus the clarification of urban functional structure and its steady changes is a necessary and important element of the geographical research.

\section{References:}

1. Anatomiâ mista: Misto ì onovlennâ [Anatomy of a city: the city and renewal]. Kyiv, 2013. (In Ukrainian).

2. Axenov K., Brade I., Bondarchuk E. The transformation of urban space in post-Soviet Russia. Taylor \& Francis, $196 \mathrm{p}$.

3. Barbara E. Public space in the "blue cities" of Russia. In: Stanilov, Kirill (Ed.). The post-socialist city: Urban form and space transformations in Central and Eastern Europe after Socialism. Dordecht, 2007, pp. 285-300. 
4. Bozhe-Garnye Zh., Shabo Zh. Ocherki po geografii gorodov [Essays on the geography of cities]. Moscow, 1967. (In Russian).

5. Brol R., Maj M., Strahl D. Metody typologii miast. Wroclaw, 1990.

6. Habermas J. The Structural Transformation of the Public Sphere. Cambridge, Massachusetts. 1991.

7. Izmenenie gorodskogo prostranstva v Ukraine [The change of urban space in Ukraine]. Ed. by L. G. Rudenko. Kyiv, 2013, 160 p. (In Russian).

8. Jacobs J. The Death and Life of Great American Cities. New York, 1961.

9. Kohn M. Brave New Neighborhoods. The Privatization of Public Space. New York and London, 2004.

10. Lefebvre H. The Production of Space. Oxford, 1991.

11. Lefebvre H. Writings on cities. Oxford, 1996.

12. Low S. How Private Interests Take Over Public Space: Zoning, Taxes, and Incorporation of Gated Communities. In: The Politics of public space. Ed. by Setha Low and Neil Smith. New York \& London, 2006, pp. 81-104.

13. Low S., Smith N. (eds.) The Politics of public space. New York \& London, 2006.

14. Lynch K. The Image of the City. Cambridge, Massachusetts, 1960.

15. Mel'ničuk A. L., Pal'čuk M. V. Sučasnì prostorovì transformaciì ìstoričnoï častini mìsta Kiêva, pov'âzanì ìz zmìnoû perevažaûčih funkcij (na prikladì Pečers'kogo rajonu) [Modern spatial transformation of historic center of Kyiv city, associated with changes of prevailing functions (case of Pechersk district)]. Geografiâ ì sučasnist': Zbirnik naukovih prac' [Geography and modernity: collection of scientific papers]. Kyiv, 2012, Series 4, Vol. 15 (27), pp. 201209. (In Ukrainian).

16. Mezencev K. V., Pìdgrušnij G. P., Mezenceva N. İ. Regional'nij rozvitok v Ukraïni: suspil'no-prostorova nerivnist' ì polârizaciâ: Monografîa [Regional development in Ukraine: socio-spatial inequality and polarization: Monograph]. Kyiv, 2014, 132 p. (In Ukrainian).

17. Mitchell D. The Right to the City: Social Justice and the Fight for Public Space. New York, 2003.

18. Rudenko L. G., Savčuk I. G. Ukraina: izmeneniâ gorodskogo prostranstva [Ukraine: the change of urban space]. Ukraïns'kij geografičnij žurnal [Ukrainian geographical journal], 2013, Vol. 4, N 2, pp. 48-56. (In Russian).

19. Stanilov K. (Ed.) The post-socialist city: Urban form and space transformations in Central and Eastern Europe after Socialism. Dordecht, 2007.

20. Zukin Sh. The Cultures of Cities. Oxford, 1995. 